\title{
Sous le regard de l'apprenti. Paliers de savoir et d'insertion chez les forgerons Moose du Yatenga (Burkina Faso)
}

Bruno Martinelli

\author{
(2) OpenEdition \\ Journals \\ Édition électronique \\ URL : https://journals.openedition.org/tc/457 \\ DOI : $10.4000 /$ tc. 457 \\ ISSN : 1952-420X \\ Éditeur \\ Éditions de l'EHESS
}

Édition imprimée

Date de publication : 1 novembre 1997

ISSN : 0248-6016

Référence électronique

Bruno Martinelli, «Sous le regard de l'apprenti. Paliers de savoir et d'insertion chez les forgerons Moose du Yatenga (Burkina Faso) », Techniques \& Culture [En ligne], 28 | 1997, mis en ligne le 28 octobre 2005, consulté le 29 septembre 2022. URL : http://journals.openedition.org/tc/457 ; DOI : https://doi.org/10.4000/tc.457

Ce document a été généré automatiquement le 29 septembre 2022.

Tous droits réservés 
Sous le regard de l'apprenti. Paliers de savoir et d'insertion chez les forgerons Moose du Yatenga (Burkina Faso)

Bruno Martinelli 